Article

\title{
Chemical Composition, Fatty Acid and Mineral Content of Food-Grade White, Red and Black Sorghum Varieties Grown in the Mediterranean Environment
}

\author{
Paola Pontieri ${ }^{1, *}$, Jacopo Troisi ${ }^{2}{ }^{\mathbb{D}}$, Matteo Calcagnile ${ }^{3} \mathbb{D}$, Scott R. Bean ${ }^{4}{ }^{\mathbb{D}}$, Michael Tilley ${ }^{4}$, Fadi Aramouni ${ }^{4}$, \\ Antonio Boffa ${ }^{1}$, Giacomo Pepe ${ }^{5}$, Pietro Campiglia ${ }^{5}\left(\mathbb{D}\right.$, Fabio Del Giudice ${ }^{6}$, Alberto L. Chessa ${ }^{7} \mathbb{D}$, \\ Dmitriy Smolensky ${ }^{4}$ D, Mariarosaria Aletta ${ }^{8}$, Pietro Alifano ${ }^{3}$ and Luigi Del Giudice ${ }^{1}$
}

check for updates

Citation: Pontieri, P.; Troisi, J.; Calcagnile, M.; Bean, S.R.; Tilley, M.; Aramouni, F.; Boffa, A.; Pepe, G.; Campiglia, P.; Del Giudice, F.; et al. Chemical Composition, Fatty Acid and Mineral Content of Food-Grade White, Red and Black Sorghum Varieties Grown in the Mediterranean Environment. Foods 2022, 11, 436 .

https://doi.org/10.3390/

foods11030436

Academic Editors: Laura Gazza and Francesca Nocente

Received: 29 December 2021

Accepted: 28 January 2022

Published: 2 February 2022

Publisher's Note: MDPI stays neutral with regard to jurisdictional claims in published maps and institutional affiliations.

Copyright: (C) 2022 by the authors. Licensee MDPI, Basel, Switzerland. This article is an open access article distributed under the terms and conditions of the Creative Commons Attribution (CC BY) license (https:// creativecommons.org/licenses/by/ $4.0 /)$.
1 Istituto di Bioscienze e BioRisorse-UOS Napoli-CNR c/o Dipartimento di Biologia, Sezione di Igiene, 80134 Napoli, Italy; boffa83@gmail.com (A.B.); luigi.delgiudice@ibbr.cnr.it (L.D.G.)

2 Theoreosrl, Spin Off of the University of Salerno, Department of Medicine and Surgery, Via Degli Ulivi, 3 , Montecorvino Pugliano, 84090 Salerno, Italy; troisi@theoreosrl.com

3 Dipartimento di Scienze e Tecnologie Biologiche e Ambientali, Università del Salento, 73100 Lecce, Italy; matteo.calcagnile@unisalento.it (M.C.); pietro.alifano@unisalento.it (P.A.)

4 USDA-ARS, CGAHR, Manhattan, KS 66502, USA; scott.bean@usda.gov (S.R.B.); michael.tilley@usda.gov (M.T.); fadi.aramouni@usda.gov (F.A.); dmitriy.smolensky@usda.gov (D.S.)

5 Department of Pharmacy, School of Pharmacy, University of Salerno, 84084 Fisciano, Italy; gipepe@unisa.it (G.P.); pcampiglia@unisa.it (P.C.)

6 Bioteam Laboratory, Via Girolamo Santacroce, 80129 Napoli, Italy; felicita24@libero.it

7 Sorghum Breeder, Fernando Camino N 15 P4 F, 29016 Málaga, Spain; alberto.chessa@outlook.com

8 DCSRSI SPR BIBLIOTECA, 80131 Napoli, Italy; mariarosaria.aletta@igb.cnr.it

* Correspondence: paola.pontieri@ibbr.cnr.it

\begin{abstract}
Grain sorghum (Sorghum bicolor) is a gluten-free cereal grown around the world and is a food staple in semi-arid and subtropical regions. Sorghum is a diverse crop with a range of pericarp colour including white, various shades of red, and black, all of which show health-promoting properties as they are rich sources of antioxidants such as polyphenols, carotenoids, as well as micro- and macro-nutrients. This work examined the grain composition of three sorghum varieties possessing a range of pericarp colours (white, red, and black) grown in the Mediterranean region. To determine the nutritional quality independent of the contributions of phenolics, mineral and fatty acid content and composition were measured. Minor differences in both protein and carbohydrate were observed among varieties, and a higher fibre content was found in both the red and black varieties. A higher amount of total saturated fats was found in the white variety, while the black variety had a lower amount of total unsaturated and polyunsaturated fats than either the white or red varieties. Oleic, linoleic, and palmitic were the primary fatty acids in all three analysed sorghum varieties. Significant differences in mineral content were found among the samples with a greater amount of $\mathrm{Mg}, \mathrm{K}, \mathrm{Al}$, $\mathrm{Mn}, \mathrm{Fe}, \mathrm{Ni}, \mathrm{Zn}, \mathrm{Pb}$ and $\mathrm{U}$ in both red and black than the white sorghum variety. The results show that sorghum whole grain flour made from grain with varying pericarp colours contains unique nutritional properties.
\end{abstract}

Keywords: sorghum; pericarp; nutrition; grain; proximate composition; minerals; lipid composition

\section{Introduction}

Sorghum (Sorghum bicolor (L.) Moench) is a widely consumed cereal staple in regions of Africa and Asia [1-8] and is the fifth leading cereal crop in the world, after the crops wheat, maize, rice, and barley [9]. The United States is the number one producer and exporter of sorghum, generating roughly $20 \%$ of total production and near $80 \%$ of total sorghum exports from 2001-2003 [10]). Where sorghum has been traditionally a basic food staple, it has also been used in several food products and in some cases health food 
items $[8,11,12]$. Sorghum does not contain peptide sequences that are toxic to persons with celiac disease, as are found in wheat, barley, and rye, and is therefore a safe food for celiac patients [13-15]. With increasing interest related to the unique properties of sorghum, its value as a food in helping to improve human health and to prevent disease has generated increasing research [1,2,4,11,15-17]. Specifically, increased research attention has focussed on the diverse content of phenolic compounds present in sorghum, which is a unique attribute among cereal grains [2]. These phenolic compounds have been shown to have various properties, e.g., inhibiting cancer cell growth [17], and while more research is needed on the health benefits of sorghum, consumption of whole grain sorghum may have the potential to help reduce health problems such as heart disease, diabetes, and obesity [16].

A current trend worldwide is a considerable preference for foods that have additional health benefits beyond basic nutrition. Research has continued to demonstrate that sorghum whole grains have numerous human health benefits, especially as related to antioxidant activity of phenolic compounds present in the outer layers of the grain [18,19]. The free radical scavenging activity of sorghum phenolic compounds has been related to beneficial health attributes, including anti-microbial properties [20], reduced oxidative stress [18], anti-inflammatory properties [21] and anti-cancer activity [17,22-25], thereby adding value to sorghum grains and its increasing human consumption [26]. The beneficial activities of sorghum for human health have been attributed mainly to the phenolic compounds found in sorghum grain and which are well known to vary with pericarp colour. While much of the research related to sorghum phenolic compounds and potential health benefits has been conducted using whole sorghum bran, or crude extracts from sorghum grain/bran, e.g., $[6,17,18,20,21]$, numerous types of polyphenols have been identified in sorghum with examples including, flavonoids, hydroxybenzoic acids and hydroxycinnamic acids with specific levels varying according to both genetics and environment [24,27]. Several varieties of sorghum exist with a wide range of pericarp colour, and which can be classified based on the pigmentation of the pericarp [28]. In particular, research has shown that total phenolic content and antioxidant activity in sorghum are correlated with the pericarp thickness and colour, and sorghum with darker and thicker pericarp had greater levels of phenolic compounds and increased antioxidant activity [28,29]. Highly pigmented sorghum may therefore be desirable for use in human foods with improved human health attributes.

Substantial research has been conducted with the aim of developing the cultivation of sorghum lines in the Mediterranean area for use in production of human food products [8,30-32]. With that overall goal, the focus of this research was to compare the nutritional composition of sorghum varieties that differed in pericarp colour to (1) determine how nutritional properties other than phenolic content varied and (2) identify varieties with improved nutritional characteristics in addition to phenolic content and thus provide greater potential health value for consumers. Additionally, this research adds to the body of knowledge on sorghum grain nutrient composition, especially for sorghum grown outside the major sorghum producing regions.

\section{Materials and Methods}

\subsection{Sorghum Cultivars}

The sorghum varieties along with seed sources used in this research are shown in Table 1. In 2019, sorghum production was conducted in San Bartolomeo in Galdo (BN) in the Fortore area, which is in the Campania Region of southern Italy $\left(41^{\circ} 25^{\prime} \mathrm{N}, 15^{\circ} 01^{\prime} \mathrm{E}\right.$ and $597 \mathrm{~m}$ a.s.l.). The soil in this region is predominantly clay loam, deep and with a good water holding capacity. The milling was carried out starting from 1 month from the harvest of the sorghum grain, which was stored in a dry environment at $16{ }^{\circ} \mathrm{C}$. 
Table 1. List of sorghum varieties.

\begin{tabular}{cclc}
\hline Variety Colour & Variety Name & \multicolumn{1}{c}{ Source } & Supplied by \\
\hline White sorghum & DSM 3-410 & Richardson Seeds Ltd. & M. Malin \\
Red sorghum & DSM IF-41912 & Richardson Seeds Ltd. & M. Malin \\
Black sorghum & DSM 212-2311 & Richardson Seeds Ltd. & M. Malin \\
\hline
\end{tabular}

\subsection{Flour Sample Preparation}

Flour samples were produced from approximately $1 \mathrm{~kg}$ of grain samples that were milled using a two-roll mill (Chopin Moulin CD1; Chopin S.A., Villeneuve la Garenne, France) and subsequently were sieved using a planetary sieve (Buhler AG, Uzwil, Switzerland) with a screen size of $120 \mu \mathrm{m}^{2}$.

\subsection{Moisture}

Moisture was determined according to the method described by Pontieri et al. [31]. Briefly, a ceramic capsule was accurately weighed after a complete desiccation at $100{ }^{\circ} \mathrm{C}$ in vacuum-packed $(25 \mathrm{~mm} \mathrm{Hg}$ ) conditions using an oven (ISCO mod. NSV9035) and chilled at room temperature in a silica gel dryer. Then, an accurately weighed aliquot of flour samples (about $2 \mathrm{~g}$ ) was placed in the desiccated ceramic capsule. The humidity was removed from the sample, by keeping it in the same temperature and pressure conditions for about five hours, until a constant weight was achieved. The moisture content was estimated by the weight loss.

\subsection{Ash}

To measure total ash, sorghum grain samples (ca. $3 \mathrm{~g}$ each) were weighed into broad, shallow ashing dishes and incinerated at $\sim 550{ }^{\circ} \mathrm{C}$, after which the dishes were placed in a desiccator to cool and then weighed after coming to room temperature [33].

\subsection{Protein Content}

Nitrogen content was measured using the Kjeldahl method [34] with total protein content determined with a conversion factor of 6.25. Sorghum grain samples ( $2 \mathrm{~g}$ each) were analysed with a Mineral Six Digester and an Auto Disteam semi-automatic distilling unit (International PBI, Milan, Italy).

\subsection{Total Lipid Content}

Total lipid content was measured as described by Pontieri et al. [30]. Briefly, approximately $3 \mathrm{~g}$ of grain was ground with liquid nitrogen using a mortar and pestle and lyophilized with the FTS-System Flex-DryTM instrument. The ground whole meal was then extracted using a Soxhlet apparatus with chloroform $\left(\mathrm{CHCl}_{3}\right)$ for $4 \mathrm{~h}$. Extracts were then dried with a rotary evaporator to obtain the crude extracts, which were subsequently weighed to determine the amount of extracted fat.

\subsection{Gas Chromatography of Fatty Acids}

Esterification of fatty acids from the crude extracts and subsequent gas chromatographic analysis of the fatty acid methyl esters was carried out as described previously [30,31]. Briefly, solid sorghum fat was melted in an oven at $50{ }^{\circ} \mathrm{C}$ to determinate its composition. A drop of fat was transferred into a $1.5 \mathrm{~mL}$-vial. One $\mathrm{ml}$ of hexane and $100 \mu \mathrm{L}$ of $2 \mathrm{~N} \mathrm{KOH}$ methanolic solution were added. The vial was vortexed for $5 \mathrm{~min}$, and then left under static conditions for $5 \mathrm{~min}$, to enable a complete stratification of the hexanic portion, which contained the methyl ester of the fatty acids. Chromatographic separation was achieved using a GC2010 (Shimadzu, Kyoto, Japan) equipped with a DB-Wax (Phenomenex, Torrance, CA, USA), $30 \mathrm{~m}$ length, $0.25 \mathrm{~mm}$ internal diameter, $0.25 \mu \mathrm{m}$ film thickness column. The GC conditions were as follows: carrier gas, He; pressure, $75 \mathrm{kPa}$; injector temperature, $220^{\circ} \mathrm{C}$; 
FID temperature, $250{ }^{\circ} \mathrm{C}$; and oven program, $170{ }^{\circ} \mathrm{C}$ for $8 \mathrm{~min}, 2^{\circ} \mathrm{C} / \mathrm{min}$ to $185^{\circ} \mathrm{C}$ for $10 \mathrm{~min}, 1^{\circ} \mathrm{C} / \mathrm{min}$ to $190{ }^{\circ} \mathrm{C}$ for $12 \mathrm{~min}, 10^{\circ} \mathrm{C} / \mathrm{min}$ to $240{ }^{\circ} \mathrm{C}$ for $5 \mathrm{~min}$.

\subsection{Carbohydrates}

Carbohydrate content was determined by subtraction as the amount of material left after accounting for moisture, ash, protein, and fat content [35].

\subsection{Fibre}

Fibre was determined according to the AOAC [36] method. Briefly, fibre was determined as the loss, after incineration, of the sample digested in an acidic environment by $\mathrm{H}_{2} \mathrm{SO}_{4}(0.255 \mathrm{~N})$, followed by an alkaline digestion with $\mathrm{NaOH}(0.223 \mathrm{~N})$. Digestion was obtained with an automatic digestor (Velp Scientific mod. FIWE3, Usmate Velate, Monza e Brianza, Italy).

\subsection{Total Minerals Determination}

The determination of the mineral elements of interest was performed according to Tenore et al. [37] as described by Pontieri et al. [38].

Briefly, for each sample, the ash content was solubilized using ultrapure water (18 $\mathrm{M} \Omega$, produced using a Millipore Direct-Q UV3 water purifier) based $\mathrm{HNO}_{3}$ (Ultrapure, Sigma Aldrich, St. Louis, MO, USA) 5\% solution. The solution was filtered using ash-free regenerated cellulose filters. All chemicals were of the highest commercially available purity grade. No glass (flask, pipettes, etc.) was used for any operation. Before use, all plastic containers were cleaned using $10 \%$ ultra-pure grade $\mathrm{HNO}_{3}$ for at least $24 \mathrm{~h}$, and then rinsed copiously with ultra-pure water before use.

Element quantification was performed using quadrupole inductively coupled plasma mass spectrometry, ICP-QMS (820-MS, Bruker Daltonics, Billerica, MA). The operational parameters were: Plasma flow: $18 \mathrm{~L} / \mathrm{min}$, Auxiliary flow: $1.8 \mathrm{~L} / \mathrm{min}$, Sheath Gas: $0.14 \mathrm{~L} / \mathrm{min}$, Nebulizer flow: $0.98 \mathrm{~L} / \mathrm{min}$, RF power: $1.40 \mathrm{~kW}$, Pump rate: $4 \mathrm{rpm}$, Stabilization delay: 20 s, First Extraction Lens: -40 volts, Second Extraction Lens: -166 volts, Third Extraction Lens: -234 volts, Corner Lens: -208 volts, Mirror Lens left: 29 volts, Mirror Lens right: 26 volts, Mirror Lens bottom: 30 volts; CRI parameters: Skimmer Gas: $\mathrm{H}_{2}$ at $50 \mathrm{~mL} / \mathrm{min}$, Sample Gas: He at $10 \mathrm{~mL} / \mathrm{min}$; dwell time, 10,000 $\mu \mathrm{s}$; no. of scan replicate: 10, no. replicate for sample: 5 . High purity He (99.9999\% He, SALDOGAS Srl, Naples, Italy) and $\mathrm{H}_{2}$ (99.9999\% $\mathrm{H}_{2}$, produced by the DBS $\mathrm{H}_{2}$ generator PGH2-300) were used, in order to minimize the potential problems caused by unidentified reactive contaminant species in the cell. Calibration solutions were prepared from multi-elemental standard stock solutions of $20.00 \mathrm{mg} / \mathrm{L}$. Calibration curves were obtained using 9 calibration solutions. Reagent blanks containing ultra-pure water were additionally analysed to control the purity of the reagents and laboratory equipment. Standards and blanks were subjected to the same treatment as the samples. A mixed solution of internal standard $\left({ }^{6} \mathrm{Li},{ }^{45} \mathrm{Sc},{ }^{72} \mathrm{Ge},{ }^{89} \mathrm{Y},{ }^{103} \mathrm{Rh}{ }^{159} \mathrm{~Tb},{ }^{165} \mathrm{Ho}\right.$, $\left.{ }^{209} \mathrm{Bi}\right) 10 \mu \mathrm{g} / \mathrm{L}$ was on-line aspired with a $\mathrm{T}$ union with the sample and standard solution.

\subsection{ELISA Assay}

The RIDASCREENR standard test kit [RIDASCREEN R Gliadin (Art. No R7001) R-Biopharm AG] sandwich ELISA based method was used to determine the presence of protein sequences reactive to gliadins in sorghum flour samples [39] following the manufacturer's instructions. Commercial gliadin standard 16-18\% N (Sigma Aldrich, Milan, Italy) was used as control.

\subsection{Statistical Analysis}

With the exception of total lipids analysis, which was performed in triplicate, all analyses were performed in quintuples $(n=5)$ (technical replicates), and the results are presented as the mean \pm SD. Data distributions were evaluated by means of Shapiro-Wilk test. As all data was not normally distributed, differences in means were investigated using 
the non-parametric Mann-Whitney U test. Analysis of variance (ANOVA) was used to assess if the different values were statistically significant or not. The Tukey post-hoc test was used to identify which samples were different. False discovery rate (FDR) corrected $p$-value was used to manage the multiple comparisons.

\section{Results}

\subsection{Nutrient Composition}

The chemical composition of white, red, and black sorghum varieties developed in the USA but produced in Southern Italy is shown in Table 2. The table also reports the recommended daily dose (RDA) according to the European legislation [40]. Minor variations in both protein and carbohydrate were observed among the three coloured sorghum varieties analysed, while a higher fibre content was found in both the red and black varieties $(p<0.05)$.

Table 2. Nutritional values of white, red, and black sorghum varieties. Abbreviation: Recommended Daily dose (RDA).

\begin{tabular}{ccccc}
\hline Parameter & White & Red & Black & RDA \\
\hline Moisture (\%) & $11.86 \pm 0.06$ & $11.92 \pm 0.04 *$ & $11.44 \pm 0.09 \S$ & \\
Ash (\%) & $1.22 \pm 0.04$ & $1.44 \pm 0.05^{*}$ & $1.88 \pm 0.06 * \S$ & \\
Total proteins (\%) & $6.14 \pm 0.10$ & $6.85 \pm 0.07^{*}$ & $7.28^{*} \pm 0.09 \S$ & $50 \mathrm{~g} /$ day \\
Fats (\%) & $2.23 \pm 0.05$ & $2.00 \pm 0.04 *$ & $1.55^{*} \pm 0.03 \S$ & $70 \mathrm{~g} /$ day \\
Total carbohydrates (\%) & $73.17 \pm 0.27$ & $71.32 \pm 0.30 *$ & $70.07 * \pm 0.39 \S$ & $260 \mathrm{~g} /$ day \\
Sugars (\%) & $0.67 \pm 0.05$ & $0.63 \pm 0.06$ & $0.77 \pm 0.06$ & $90 \mathrm{~g} /$ day \\
Fibres (\%) & $5.37 \pm 0.14$ & $6.46 \pm 0.29 *$ & $7.78 \pm 0.24{ }^{*} \S$ & \\
\hline
\end{tabular}

FDR corrected $p$-value $<0.05$ comparing to white sorghum was indicated as ${ }^{*}$, while comparing to red sorghum as §.

\subsection{Fatty Acid Composition of Total Lipids}

The percentages of total fatty acids, also aggregated as saturated, mono-unsaturated and polyunsaturated fats, of white, red and black sorghum varieties are shown in Table 3. Greater levels of total saturated fats $\left({ }^{*} p<0.05\right)$ was found in the white variety than in the red and black varieties, while the black variety had a lesser amount of total unsaturated and polyunsaturated fats $\left({ }^{*} p<0.05\right)$ than both the white and red varieties.

Table 3. Fatty acid content (g per $100 \mathrm{~g}$ raw fat) of white, red, and black sorghum varieties.

\begin{tabular}{cccc}
\hline Fatty Acid & White & Red & Black \\
\hline Myristic acid & $0.013 \pm 0.000$ & $0.012 \pm 0.000$ & $0.036 \pm 0.000 * \S$ \\
Palmitic acid & $18.633 \pm 0.001$ & $17.322 \pm 0.01 *$ & $12.769 \pm 0.001 * \S$ \\
Palmitoleic acid & $0.824 \pm 0.002$ & $0.792 \pm 0.002$ & $0.690 \pm 0.001 * \S$ \\
Margaric acid & $0.064 \pm 0.534$ & $0.065 \pm 0.537$ & $0.099 \pm 0.385 * \S$ \\
Margaroleic acid & $0.063 \pm 0.447$ & $0.061 \pm 0.421$ & $0.067 \pm 0.0438 * \S$ \\
Stearic acid & $2.226 \pm 0.613$ & $2.236 \pm 0.598$ & $1.234 \pm 0.599 * \S$ \\
Oleic acid & $37.62 \pm 0.031$ & $42.655 \pm 0.029 *$ & $40.178 \pm 0.018 * \S$ \\
Linoleic acid & $35.707 \pm 0.062$ & $33.985 \pm 0.058$ & $42.084 \pm 0.052 * \S$ \\
Linolenic acid & $2.051 \pm 0.087$ & $1.958 \pm 0.081$ & $2.084 \pm 0.091 * \S$ \\
Arachidic acid & $0.435 \pm 0.026$ & $0.374 \pm 0.025 *$ & $0.214 \pm 0.028 * \S$ \\
Eicosenoic acid & $0.302 \pm 0.023$ & $0.274 \pm 0.021 *$ & $0.220 \pm 0.022 * \S$ \\
Behenic acid & $0.072 \pm 0.021$ & $0.061 \pm 0.019 *$ & $0.027 \pm 0.023 * \S$ \\
Lignoceric acid & $0.203 \pm 0.015$ & $0.188 \pm 0.013 *$ & $0.232 \pm 0.018 * \S$ \\
Erucic acid & $0.019 \pm 0.015$ & $0.018 \pm 0.013$ & $0.065 \pm 0.014 * \S$ \\
\hline Saturated fats & $0.52 \pm 0.05$ & $0.41 \pm 0.04 *$ & $0.22 \pm 0.03 * \S$ \\
Monounsaturated fats & $0.85 \pm 0.02$ & $0.89 \pm 0.01$ & $0.64 \pm 0.02 * \S$ \\
Polyunsaturated fats & $0.86 \pm 0.07$ & $0.71 \pm 0.02 *$ & $0.69 \pm 0.02 *$
\end{tabular}

FDR corrected $p$-value $<0.05$ comparing to white sorghum was indicated as *, while comparing to red sorghum as §. 
Oleic, linoleic, and palmitic, were the primary fatty acids in all three of the sorghum varieties analysed, which is in agreement with previously reported results [31,41,42]. The percentage of palmitic acid in the black sorghum variety was slightly lower than both the white and red varieties, while the percentage of linoleic acid was slightly higher in the black variety than in the white and red varieties. Finally, the percentage of oleic acid was comparable between the three varieties of sorghum.

\subsection{Mineral Content}

Levels of minerals from the three sorghum varieties are reported in Table 4. Statistical analysis was not performed on the mineral content due to the number of minerals tested. However, the levels of macro-elements followed the sequence $\mathrm{K}>\mathrm{Mg}>\mathrm{Ca}>\mathrm{Na}$ in all three varieties analysed. Micro-element content followed the sequence $\mathrm{Fe}>\mathrm{Zn}>\mathrm{Al}>\mathrm{Mn}>\mathrm{Cr}>$ $\mathrm{Ni}>\mathrm{Cu}>\mathrm{Ba}>\mathrm{Mo}>\mathrm{Pb}>\mathrm{Co}>\mathrm{Sn}>\mathrm{Ag}>\mathrm{As}>\mathrm{Se}>\mathrm{V}>\mathrm{Be}>\mathrm{Tl}$ in the white variety, while the content of micro-elements followed the sequence $\mathrm{Fe}>\mathrm{Zn}>\mathrm{Al}>\mathrm{Mn}>\mathrm{Ni}>\mathrm{Cu}>\mathrm{Cr}>$ $\mathrm{Ba}>\mathrm{Mo}>\mathrm{Pb}>\mathrm{Co}>\mathrm{Sn}>\mathrm{Ag}>\mathrm{As}>\mathrm{Se}>\mathrm{V}>\mathrm{Be}>\mathrm{Tl}$ in both the red and black varieties analysed. The white variety had a lower element content than that of both the red and black varieties, with $\mathrm{K}, \mathrm{Fe}$ and $\mathrm{Sb}$ were the most abundant macro-element, micro-element, and trace element in all analysed varieties, except $\mathrm{Hg}$ which was the most abundant trace element in the white variety. The potassium and sodium content of the samples varied from 26.89 to $35.66 \mathrm{~g} \mathrm{~kg}^{-1}$ and 0.42 to $0.54 \mathrm{~g} \mathrm{~kg}^{-1}$, respectively, with the potassium content of the samples ranging from about 64-fold to 66-fold higher than that of sodium. Therefore, the K:Na ratio was higher than the recommended ratio 5.0 [43] for the human diet. The fact that the sorghum hybrids all contained a high K:Na ratio suggests that sorghum could be used to modulate sodium-related health problems. In fact, diets with a higher K:Na ratio are recommended for certain health conditions such as [44].

Table 4. Elements content in sorghum varieties. Abbreviation: Recommended Daily dose (RDA).

\begin{tabular}{|c|c|c|c|c|c|}
\hline Metal & Unit & White & Red & Black & RDA \\
\hline K & $\mathrm{g} / \mathrm{Kg}$ & $26.89 \pm 0.62$ & $32.02 \pm 0.68^{*}$ & $35.66 \pm 0.61 * \S$ & $2.0 \mathrm{~g} / \mathrm{day}$ \\
\hline $\mathrm{Mg}$ & $\mathrm{g} / \mathrm{Kg}$ & $8.69 \pm 0.35$ & $12.86 \pm 0.22 *$ & $16.93 \pm 0.41 * \S$ & $0.375 \mathrm{~g} /$ day \\
\hline $\mathrm{Ca}$ & $\mathrm{g} / \mathrm{Kg}$ & $1.25 \pm 0.03$ & $2.16 \pm 0.03 *$ & $2.88 \pm 0.08 * \S$ & $0.8 \mathrm{~g} /$ day \\
\hline $\mathrm{Na}$ & $\mathrm{g} / \mathrm{Kg}$ & $0.42 \pm 0.04$ & $0.43 \pm 0.01$ & $0.54 \pm 0.01 * \S$ & \\
\hline $\mathrm{Fe}$ & $\mathrm{mg} / \mathrm{Kg}$ & $346.91 \pm 1.35$ & $578.75 \pm 1.42 *$ & $655.15 \pm 1.37 * \S$ & $14 \mathrm{mg} /$ day \\
\hline $\mathrm{Zn}$ & $\mathrm{mg} / \mathrm{Kg}$ & $180.21 \pm 0.86$ & $250.47 \pm 5.34$ * & $284.35 \pm 7.59 * \S$ & $10 \mathrm{mg} /$ day \\
\hline $\mathrm{Al}$ & $\mathrm{mg} / \mathrm{Kg}$ & $54.59 \pm 0.54$ & $179.01 \pm 5.43^{*}$ & $200.01 \pm 4.68 * \S$ & \\
\hline $\mathrm{Mn}$ & $\mathrm{mg} / \mathrm{Kg}$ & $49.81 \pm 1.22$ & $79.44 \pm 2.58^{*}$ & $98.68 \pm 2.53 * \S$ & $2 \mathrm{mg} /$ day \\
\hline $\mathrm{Cr}$ & $\mathrm{mg} / \mathrm{Kg}$ & $31.17 \pm 1.13$ & $43.54 \pm 1.55^{*}$ & $53.74 \pm 0.61 * \S$ & $0.04 \mathrm{mg} /$ day \\
\hline $\mathrm{Ni}$ & $\mathrm{mg} / \mathrm{Kg}$ & $29.32 \pm 0.51$ & $40.13 \pm 0.78^{*}$ & $49.91 \pm 1.46 * \S$ & \\
\hline $\mathrm{Cu}$ & $\mathrm{mg} / \mathrm{Kg}$ & $24.11 \pm 0.49$ & $31.83 \pm 0.88^{*}$ & $35.56 \pm 0.83 * \S$ & $1 \mathrm{mg} /$ day \\
\hline $\mathrm{Ba}$ & $\mathrm{mg} / \mathrm{Kg}$ & $4.63 \pm 0.14$ & $6.46 \pm 0.25 *$ & $8.00 \pm 0.08 * \S$ & \\
\hline Mo & $\mathrm{mg} / \mathrm{Kg}$ & $1.15 \pm 0.03$ & $1.62 \pm 0.02 *$ & $2.05 \pm 0.05 * \S$ & $0.05 \mathrm{mg} /$ day \\
\hline $\mathrm{Pb}$ & $\mathrm{mg} / \mathrm{Kg}$ & $0.57 \pm 0.06$ & $1.39 \pm 0.04 *$ & $1.61 \pm 0.06 * \S$ & \\
\hline Co & $\mathrm{mg} / \mathrm{Kg}$ & $0.50 \pm 0.02$ & $0.96 \pm 0.01 *$ & $1.07 \pm 0.01 * \S$ & \\
\hline Sn & $\mathrm{mg} / \mathrm{Kg}$ & $0.17 \pm 0.01$ & $0.31 \pm 0.01^{*}$ & $0.39 \pm 0.01 * \S$ & \\
\hline $\mathrm{Ag}$ & $\mathrm{mg} / \mathrm{Kg}$ & $0.17 \pm 0.01$ & $0.30 \pm 0.01 *$ & $0.34 \pm 0.01 * \S$ & \\
\hline As & $\mathrm{mg} / \mathrm{Kg}$ & $0.63 \pm 0.01$ & $0.23 \pm 0.01 *$ & $0.28 \pm 0.01 * \S$ & \\
\hline Se & $\mathrm{mg} / \mathrm{Kg}$ & $0.08 \pm 0.01$ & $0.05 \pm 0.01 *$ & $0.07 \pm 0.01 * \S$ & $0.055 \mathrm{mg} /$ day \\
\hline $\mathrm{V}$ & $\mathrm{mg} / \mathrm{Kg}$ & $<0.01$ & $<0.01$ & $<0.01$ & \\
\hline $\mathrm{Be}$ & $\mathrm{mg} / \mathrm{Kg}$ & $<0.01$ & $<0.01$ & $<0.01$ & \\
\hline $\mathrm{Tl}$ & $\mathrm{mg} / \mathrm{Kg}$ & $<0.01$ & $<0.01$ & $<0.01$ & \\
\hline $\mathrm{Sb}$ & $\mu \mathrm{g} / \mathrm{Kg}$ & $38.62 \pm 0.90$ & $64.69 \pm 1.10 *$ & $79.80 \pm 2.01 * \S$ & \\
\hline $\mathrm{Hg}$ & $\mu \mathrm{g} / \mathrm{Kg}$ & $61.56 \pm 3.08$ & $50.81 \pm 2.06^{*}$ & $62.70 \pm 2.20 \S$ & \\
\hline $\mathrm{Cd}$ & $\mu \mathrm{g} / \mathrm{Kg}$ & $11.86 \pm 0.20$ & $32.90 \pm 0.68 *$ & $36.93 \pm 0.86 * \S$ & \\
\hline $\mathrm{U}$ & $\mu \mathrm{g} / \mathrm{Kg}$ & $3.14 \pm 0.05$ & $5.54 \pm 0.13^{*}$ & $6.21 \pm 0.12 * \S$ & \\
\hline
\end{tabular}

FDR corrected $p$-value $<0.05$ comparing to white sorghum was indicated as *, while comparing to red sorghum as §. 


\subsection{Immunochemical Evidence for the Absence of Gluten in Coloured Sorghum Varieties}

Immunochemical measurement of gliadin concentration in the sorghum flour from all samples tested showed that gluten levels in all sorghum cultivars were less than $5 \mathrm{ppm}$ (the detectable limit) (Table 5) and are at levels substantially below the $20 \mathrm{mg} / \mathrm{kg}$ (ppm) threshold recommended as safe for celiac patients [39].

Table 5. Measurement of gliadin (as ppm) in flours by using sandwich R5 enzyme-linked immunosorbent assay (ELISA).

\begin{tabular}{ccc}
\hline Variety & Type & Content $(\mathbf{p p m})^{2}$ \\
\hline White & Sorghum & $<5$ \\
Red & Sorghum & $<5$ \\
Black & Sorghum & $<5$ \\
Gliadin standard $^{1}$ & Wheat & 56 \\
\hline
\end{tabular}

${ }^{1}$ Gliadin standard from wheat (Sigma). ${ }^{2}$ Mean values from 3 measurements.

\section{Discussion}

As it has been reported that pericarp colour of sorghum grain may vary due to both genotype environmental factors $[42,45,46]$, in this work we compared both the chemical composition and the content of fatty acids and the mineral content of three coloured varieties of sorghum grown in the Mediterranean environment of Southern Italy. The search for varieties of sorghum developed in the USA that have high functional and nutraceutical properties when grown in the Mediterranean area will stimulate the use of sorghum for human use as a health food in European countries; it may encourage European farmers to produce sorghum, as it is a drought tolerant plant very well suited to environmental changes [8].

The composition profiles of white, red, and black food-grade sorghum varieties developed in the USA, and grown in Southern Italy, were overall similar with slight differences in both protein and carbohydrate percentages. The higher fibre content found in the red and black varieties suggests that this variety may have health benefits in addition to those conferred from just phenolic compounds. The black sorghum also had slightly higher total protein levels and less total fat, which could be minor benefits for use of black sorghum flour in human food products.

The quantities of the total saturated and mono-unsaturated fats of both the white and red varieties were similar and higher than those of the black variety, while the red and black varieties had similar quantities of total polyunsaturated fats but lower than that of the white variety. Thus, the black variety analysed in this research may have a slight nutritional advantage related to consumption of saturated fat relative the other two varieties. Oleic, linoleic, and palmitic were the primary fatty acids in all the sorghum varieties. Unsaturated fatty acids are important for human nutrition, as they are major components of biological membranes and play a role in modulating the fluidity of membranes. Additionally, unsaturated fatty acids do not have cholesterogenic properties (unlike saturated fatty acids), and reduce the risk of thrombosis, due to anti-aggregating activity of blood lipoprotein particles. Because of these features, unsaturated fatty acids are strongly recommended to lower the risk of atherosclerosis $[4,11,16]$. The sorghum samples analysed in this work all contained some levels of unsaturated fatty acids and could supplement other plant-based sources of unsaturated fats in human diets.

The content of each macro-element followed the sequence $\mathrm{K}>\mathrm{Mg}>\mathrm{Ca}>\mathrm{Na}$ in all three coloured sorghum varieties analysed with the primary mineral being $\mathrm{K}$, followed by $\mathrm{Mg}$, which is consistent with the literature [38,47-49]. Furthermore, the concentrations of the above four macro-elements were higher in the red and black sorghum varieties than in the white sorghum variety, confirming previous works whose results indicate that the mineral content of sorghum was affected by both genetic and environmental factors [38]. With regards to macro-element content, this research reported a K:Na ratio greater than what is 
recommended in the human diet for all sorghum varieties analysed [43]. An improved K:Na ratio may improve bone health, lessen muscle loss, and moderate other chronic diseases such as hypertension and stroke [44]. In addition to the above, the magnesium content in the sorghum varieties was greater than typically found in corn (on average, $0.47 \mathrm{~g} \mathrm{~kg}^{-1}$ ) and wheat flour (on average, $0.25 \mathrm{~g} \mathrm{~kg}^{-1}$ ) [50]. Because each of the three types of coloured sorghum varieties analysed have high magnesium content, these sorghum varieties may be good sources of magnesium. Magnesium is an important macro-element because it is required for the function of many enzyme systems and therefore human metabolism [50].

The content of micro-elements followed the sequence $\mathrm{Fe}>\mathrm{Zn}>\mathrm{Al}>\mathrm{Mn}>\mathrm{Cr}>\mathrm{Ni}>\mathrm{Cu}$ $>\mathrm{Ba}>\mathrm{Mo}>\mathrm{Pb}>\mathrm{Co}>\mathrm{Sn}>\mathrm{Ag}>\mathrm{As}>\mathrm{Se}>\mathrm{V}>\mathrm{Be}>\mathrm{Tl}$ in the white variety analysed, while the content of micro-elements followed the sequence $\mathrm{Fe}>\mathrm{Zn}>\mathrm{Al}>\mathrm{Mn}>\mathrm{Ni}>\mathrm{Cu}>\mathrm{Cr}>\mathrm{Ba}$ $>\mathrm{Mo}>\mathrm{Pb}>\mathrm{Co}>\mathrm{Sn}>\mathrm{Ag}>\mathrm{As}>\mathrm{Se}>\mathrm{V}>\mathrm{Be}>\mathrm{Tl}$ in both red and black varieties analysed The differences in the concentrations of some micro-elements between the white sorghum variety and both red and black sorghum varieties reported above could be affected by the sorghum variety, soil conditions and the state of plant maturity at harvest [38]. The most abundant micro-element was Fe in all three sorghum varieties analysed, confirming the data reported in the literature $[38,46,49]$. The latter is an essential micro-element in human nutrition, and Fe-deficiency is a major public health threat worldwide [6]. The expanding production of sorghum for human use in the US [11] and in Mediterranean countries [8], suggests the use of this cereal for healthy nutrition. Thus, identifying sorghum varieties with the highest levels of Fe is beneficial when identifying sorghum varieties for production in Europe.

The concentrations of trace element content followed the sequence $\mathrm{Hg}>\mathrm{Sb}>\mathrm{Cd}>\mathrm{U}$ in the white variety, while it followed the sequence $\mathrm{Sb}>\mathrm{Hg}>\mathrm{Cd}>\mathrm{U}$ in both red and black varieties. Importantly, with regards to the trace elements $\mathrm{Sb}, \mathrm{Hg}, \mathrm{Cd}, \mathrm{U}$, their concentration in the three sorghum hybrids analysed in this study did not exceed the maximum permitted by Regulation (CE) n. 41/2009.

Regarding the micro-elements content, the results reported in the present study show high content of both Fe and $\mathrm{Zn}$ in all sorghums. The latter two elements are essential micro-elements in human nutrition, and Fe and $\mathrm{Zn}$ deficiencies are worldwide public health issues [6].

Furthermore, in this work, the sorghum varieties developed in the USA and grown in the Mediterranean environment were also analysed immunochemically to measure the concentration of gliadin to verify previous reports on safety of sorghum for people with celiac disease. As shown in Table 5, the results indicated that the gluten levels in all sorghum cultivars were less than $5 \mathrm{mg} / \mathrm{kg}$ (below detectable limits) which is below the $20 \mathrm{mg} / \mathrm{kg}$ level proposed as a safe level for celiac patients [39] and agrees with previous results [13-15].

\section{Conclusions}

Consumers worldwide have increasingly expressed interest in both functional and nutraceutical foods due to the additional health benefits provided through their consumption. Substantial research has been focused on identifying the mechanisms associated with the disease prevention or therapeutic potential of such foods. One example of a functional and nutraceutical food that has received increased research attention is sorghum grain. It is well known that sorghum is a genetically diverse crop-that diversity extends to the presence of phenolic content and composition, and results in phenotypic expression in sorghum grain with a range of pericarp colours. Sorghum has been studied for several potential human health benefits, including the role of sorghum phenolic compounds present in types of sorghum that vary in pericarp colour. The present study supports the continued strategy of evaluating sorghum with a range of pericarp colour not only for the properties of their phenolic compounds, but also for additional nutritional properties such as protein and carbohydrate contents, levels of unsaturated fatty acids and minerals. Sorghum varieties developed for production in the USA and grown in the Mediterranean region demonstrate 
the feasibility of producing a range of different sorghums that vary in polyphenolic content and the high antioxidant capacity of the compound eriodictyol-O-hexoside isolated from the red sorghum variety, a flavonoid very important for human health due to its ability to fight free radicals with high efficiency [51]. The current research provides valuable information on nutrient composition of sorghum and supports the growing research on the unique health benefits of sorghum whole grain consumption. This research also shows that sorghum varying in pericarp colour and in associated phenolic compounds [50] can also vary in overall nutrient composition.

Cereals have long been consumed by humans and are staple foods providing a primary source of carbohydrates, proteins, B vitamins and minerals for a substantial portions of the world's population; this is especially so where sorghum is consumed as the primary food source. Sorghum also contains a variety of phytochemicals which may, in addition to basic nutrition, provide some of the health benefits seen in populations consuming primarily plant food-based diets [47]. The fact that the nutritional composition was similar between the same varieties of sorghum grown in the USA and in the Mediterranean area is confirmation that it is possible to utilize sorghum for human use in Europe.

Author Contributions: Conceptualization, P.P., J.T., P.A., L.D.G.; Resources (cultivation of the three varieties in the field), A.B., A.L.C.; writing-original draft preparation, S.R.B., M.T., F.A., D.S., L.D.G., P.P.; writing-review and editing, F.D.G., M.A.; visualization, M.C., G.P., P.C. All authors have read and agreed to the published version of the manuscript.

Funding: The research was supported by both MIUR-PON03PE_00060_2, Decreto di Concessione del 27/06/2014, Progetto 2 "Progettazione, sviluppo e produzione di cibi funzionali e/o arricchiti", (OR4: Farine funzionali e prodotti da forno per celiaci ed intolleranti al glutine) to P. Pontieri and by both CNR-DISBA project "NutrAge" (project nr. 7022) and CNR project FOE-2019 DBA.AD003.139. Part of this work was supported by USDA-ARS (project nr. 3020-3440-002).

Institutional Review Board Statement: Not applicable.

Informed Consent Statement: Not applicable.

Data Availability Statement: All the data are reported in the paper.

Acknowledgments: The authors are grateful to Francesco Salamini for helpful discussion and critical reading of the manuscript. Thanks also to Matthew Malin for a generous gift of the food-grade white, red and black coloured sorghum varieties. The technical assistance of both Federico Gomez Paloma and Concetta Porzio is acknowledged. Names are necessary to report factually on available data; however, the U.S. Department of Agriculture neither guarantees nor warrants the standard of the product and use of the name by the U.S. Department of Agriculture implies no approval of the product to the exclusion of others that may also be suitable.

Conflicts of Interest: The authors declare no conflict of interest. Mention of trade names or commercial products in this publication is solely for the purpose of providing specific information and does not imply recommendation or endorsement by the U.S. Department of Agriculture. USDA is an equal opportunity provider and employer.

\section{References}

1. Anglani, C. Sorghum for human food: A review. Plant Food Hum. Nutr. 1998, 52, 85-89. [CrossRef]

2. Awika, J.M.; Rooney, L.W. Sorghum phytochemicals and their potential aspects on human health. Phytochemistry 2004, 65, 1199-1221. [CrossRef]

3. Kresovich, S.; Barbazuk, B.; Bedell, J.A. Toward sequencing the sorghum genome. A US National Science Foundation-sponsored Work Report. Plant Physiol. 2005, 138, 1898-1902.

4. Dicko, M.H.; Gruppen, H.; Traoré, A.S.; Voragen, A.G.J.; van Barkel, W.J.H. Sorghum grain as human food in Africa: Relevance of content of starch and amylase activities. Afr. J. Biotechnol. 2006, 5, 384-395.

5. Reddy, B.V.S.; Ramesh, S.; Sanjana-Reddy, P.; Ashok-Kumar, A. Genetic enhancement for drought tolerance in sorghum. Plant Breed. Rev. 2009, 31, 189-222.

6. Ashok-Kumar, A.; Reddy, B.V.S.; Sahrawat, K.L.; Ramaiah, B. Combating micronutrient malnutrition: Identification of commercial sorghum cultivars with high grain iron and zinc. J. SAT Agric. Res. 2010, 8, 1-5. 
7. Elhassan, M.S.M.; Emmambux, M.N.; Hays, D.B.; Peterson, G.C.; Taylor, J.R.N. Novel biofortified sorghum lines with combined waxy (high amylopectin) starch and high protein digestibility traits: Effects on endosperm and flour properties. J. Cereal Sci. 2015, 65, 132-139. [CrossRef]

8. Pontieri, P.; Del Giudice, L. Sorghum: A Novel and Healthy Food. In The Encyclopedia of Food and Health; Caballero, B., Finglas, P., Toldrà, F., Eds.; Elsevier: Amsterdam, The Netherlands, 2016; pp. 33-42.

9. FAO. FAOSTAT. World Crops Website. Available online: www.fao.org/faostat/en/\#data/QC (accessed on 30 March 2019).

10. USDA (United States Department of Agriculture) Foreign Agriculture Division. 2003. Available online: www.fas.usda.gov/psd (accessed on 30 March 2019).

11. Taylor, J.R.N.; Schober, T.J.; Bean, S.R. Novel food and non-food uses for sorghum and millets. J. Cereal Sci. 2006, $44,252-271$. [CrossRef]

12. Awika, J.M. Chapter 3-sorghum: Its Unique Nutritional and Health-Promoting Attributes. In Gluten-Free Ancient Grains; Taylor J.R.N., Awika, J., Eds.; Woodhead Publishing: Sawston, UK, 2017; pp. 21-54.

13. Kasarda, D.D. Grains in relation to celiac disease. Cereal Foods World 2001, 46, 209-210.

14. Ciacci, C.; Maiuri, L.; Caporaso, N.; Bucci, C.; Del Giudice, L.; Massardo, D.R.; Pontieri, P.; Di Fonzo, N.; Bean, S.R.; Ioerger, B.; et al. Celiac Disease: In Vitro and In Vivo Safety and Palatability of Wheat-Free Sorghum Food Products. Clin. Nutr. 2007, 26, 799-805. [CrossRef]

15. Pontieri, P.; Mamone, G.; De Caro, S.; Tuinstra, M.R.; Roemer, E.; Okot, J.; De Vita, P.; Ficco, D.B.; Alifano, P.; Pignone, D.; et al. Sorghum, a healthy and gluten-free food for celiac patients as demonstrated by genome, biochemical and immunochemical analyses. J. Agric. Food Chem. 2013, 61, 2565-2571. [CrossRef]

16. Stefoska-Needham, A.; Beck, E.J.; Johnson, S.K.; Tapsell, L.C. Sorghum: An underutilized cereal whole grain with the potential to assist in the prevention of chronic disease. Food Rev. Int. 2015, 31, 401-437. [CrossRef]

17. Smolensky, D.; Rhodes, D.; McVey, D.S.; Fawver, Z.; Perumal, R.; Herald, T.; Noronha, L. High-polyphenol sorghum bran extract inhibits cancer cell growth through ROS induction, cell cycle arrest, and apoptosis. J. Med. Food 2018, 21, 990-998. [CrossRef]

18. Khan, I.; Yousif, A.M.; Johnson, S.K.; Gamlath, S. Acute effect of sorghum flourcontaining pasta on plasma total polyphenols, antioxidant capacity and oxidative stress markers in healthy subjects: A randomised controlled trial. Clin. Nutr. 2015, 34, 415-421. [CrossRef]

19. Khoddami, A.; Truong, H.H.; Liu, S.Y.; Roberts, T.H.; Selle, P.H. Concentrations of specific phenolic compounds in six red sorghums influence nutrient utilisation in broiler chickens. Anim. Feed Sci. Technol. 2015, 210, 190-199. [CrossRef]

20. Kil, H.Y.; Seong, E.S.; Ghimire, B.K.; Chung, I.M.; Kwon, S.S.; Goh, E.J.; Heo, K.; Kim, M.J.; Lim, J.D.; Lee, D.; et al. Antioxidant and antimicrobial activities of crude sorghum extract. Food Chem. 2009, 115, 1234-1239. [CrossRef]

21. Burdette, A.; Garner, P.L.; Mayer, E.P.; Hargrove, J.L.; Hartle, D.K.; Greenspan, P. Anti-inflammatory activity of select sorghum (Sorghum bicolor) brans. J. Med. Food 2010, 13, 879-887. [CrossRef]

22. Awika, J.M.; Yang, L.Y.; Browning, J.D.; Faraj, A. Comparative antioxidant, antiproliferative and phase II enzyme inducing potential of sorghum (Sorghum bicolor) varieties. LWT-Food Sci. Technol. 2009, 42, 1041-1046. [CrossRef]

23. Wu, L.; Huang, Z.H.; Qin, P.Y.; Yao, Y.; Meng, X.J.; Zou, J.Q.; Zhu, K.; Ren, G.X. Chemical characterization of a procyanidin-rich extract from sorghum bran and its effect on oxidative stress and tumor inhibition in vivo. J. Agric. Food Chem. 2011, 59, 8609-8615. [CrossRef]

24. Rao, S.; Santhakumar, A.B.; Chinkwo, K.A.; Wu, G.; Johnson, S.K.; Blanchard, C.L. Characterization of phenolic compounds and antioxidant activity in sorghum grains. J. Cereal Sci. 2018, 84, 103-111. [CrossRef]

25. de Morais Cardoso, L.; Pinheiro, S.S.; Martino, H.S.D.; Pinheiro-Sant'Ana, H.M. Sorghum (Sorghum bicolor L.): Nutrients, bioactive compounds, and potential impact on human health. Crit. Rev. Food Sci. Nutr. 2017, 57, 372-390. [CrossRef]

26. Francis, N.; Rao, S.; Blanchard, C.; Santhakumar, A. Black Sorghum Phenolic Extract Regulates Expression of Genes Associated with Oxidative Stress and Inflammation in Human Endothelial Cells. Molecules 2019, 24, 3321. [CrossRef]

27. Wu, G.; Johnson, S.K.; Bornman, J.F.; Bennett, S.J.; Clarke, M.W.; Singh, V.; Fang, Z. Growth temperature and genotype both play important roles in sorghum grain phenolic composition. Sci. Rep. 2016, 6, 21835. [CrossRef]

28. Dykes, L.; Rooney, L.W.; Waniska, R.D.; Rooney, W.L. Phenolic compounds and antioxidant activity of sorghum grains of varying genotypes. J. Agric. Food Chem. 2005, 53, 6813-6818. [CrossRef]

29. Xiong, Y.; Zhang, P.; Johnson, S.; Luo, J.; Fang, Z. Comparison of the phenolic contents, antioxidant activity and volatile compounds of different sorghum varieties during tea processing. J. Sci. Food Agric. 2020, 100, 978-985. [CrossRef]

30. Pontieri, P.; Di Maro, A.; Tamburino, R.; De Stefano, M.; Tilley, M.; Bean, S.R.; Roemer, E.; De Vita, P.; Alifano, P.; Del Giudice, L.; et al. Chemical composition of selected food-grade sorghum varieties grown under typical mediterranean conditions. Maydica 2010, 55, 139-143.

31. Pontieri, P.; Di Fiore, R.; Troisi, J.; Bean, S.R.; Roemer, E.; Okot, J.; Alifano, P.; Pignone, D.; Del Giudice, L.; Massardo, D.R. Chemical composition and fatty acid content of white food sorghums grown in different environments. Maydica 2011, 56, 1-7.

32. Pontieri, P.; De Vita, P.; Boffa, A.; Tuinstra, M.R.; Bean, S.R.; Krishnamoorthy, G.; Miller, C.; Roemer, E.; Alifano, P.; Pignone, D.; et al. Yield and morpho-agronomical evaluation of food-grade white sorghum hybrids grown in Southern Italy. J. Plant Interact. 2012, 3, 49-55. [CrossRef]

33. Association of Analytical Chemists Official Method, 923. 03. Ash of flour, direct method. J. AOAC Inter. 1923, 7, 132. 
34. Association of Analytical Chemists Official Method, 920.87. Protein (total) in flour. 1920. Available online: http://www. aoacofficialmethod.org/index.php?main_page=product_info\&cPath=1\&products_id=2282 (accessed on 25 January 2021).

35. Arienzo, M.; De Martino, A.; Capasso, R.; Di Maro, A.; Parente, A. Analysis of carbohydrates and amino acids in vegetable waste waters by ion chromatography. Phytochem. Anal. 2003, 14, 74-82. [CrossRef]

36. Association of Analytical Chemists Official Method, 962.09. Fiber (Crude) in Animal Feed and Pet Food. In Official Methods of Analysis AOC International, 16th ed.; Cunniff, P., Ed.; AOAC: Rockville, MD, USA, 1995.

37. Tenore, G.C.; Troisi, J.; Di Fiore, R.; Basile, A.; Novellino, E. Chemical composition, antioxidant and antimicrobial properties of Rapa Catozza Napoletana (Brassica rapa L. var. rapa DC.) seed meal, a promising protein source of Campania region (southern Italy) horticultural germplasm. J. Sci. Food Agric. 2012, 92, 1716-1724. [CrossRef]

38. Pontieri, P.; Troisi, J.; Di Fiore, R.; Di Maro, A.; Bean, S.R.; Tuinstra, M.R.; Roemer, E.; Boffa, A.; Del Giudice, F.; Pizzolante, G.; et al. Mineral content in grains of seven food-grade sorghum hybrids grown in a Mediterranean environment. Aust. J. Crop Sci. 2014, 8 , 1550-1559.

39. Valdés, I.; García, E.; Llorente, M.; Méndez, E. Innovative approach to low-level gluten determination in foods using a novel sandwich enzyme-linked immunosorbent assay protocol. Eur. J. Gastroenterol. Hepatol. 2003, 15, 465-474. [CrossRef]

40. Regulation (EU) No 1169/2011 of the European Parliament and of the Council of 25 October 2011 "on the provision of food information to consumers, amending Regulations (EC) No 1924/2006 and (EC) No 1925/2006 of the European Parliament and of the Council, and Repealing Commission Directive 87/250/EEC, Council Directive 90/496/EEC, Commission Directive 1999/10/EC, Directive 2000/13/EC of the European Parliament and of the Council, Commission Directives 2002/67/EC and 2008/5/EC and Commission Regulation (EC) No 608/2004". Available online: https:/ / eur-lex.europa.eu/legal-content/IT/ TXT/?uri=celex\%3A32011R1169 (accessed on 25 January 2021).

41. Osagie, A.U. Total lipids of sorghum grain. J. Agric. Food Chem. 1987, 35, 601-604. [CrossRef]

42. Serna-Saldivar, S.O.; Rooney, L.W. Structure and Chemistry of Sorghum and Millets. In Sorghum and Millets: Chemistry and Technology; Dendy, D.A.V., Ed.; American Association of Cereal Chemists: St. Paul, MN, USA, 1995.

43. Szentmihalyi, K.; Kéry, A.; Then, M.; Lakatos, B.; Sándor, Z.; Vinkler, P. Potassium-sodium ratio for the characterisation of medicinal plant extracts with diuretic activity. Phytother. Res. 1998, 12, 163-166. [CrossRef]

44. Arbeit, M.L.; Nicklas, T.A.; Berenson, G.S. Considerations of dietary sodium/potassium/energy ratios of selected foods. J. Am. Coll. Nutr. 1992, 11, 210-222. [CrossRef]

45. Girard, A.L.; Awika, J.M. Sorghum polyphenols and other bioactive components as functional and health promoting food ingredients. J. Cereal Sci. 2018, 84, 112-124. [CrossRef]

46. Taleon, V.; Dykes, L.; Rooney, W.L.; Rooney, L.W. Effect of genotype and environment on flavonoid concentration and profile of black sorghum grains. Cereal Sci. 2012, 56, 470-475. [CrossRef]

47. Nutrition Foundation Task Force. Plants: Diet. and Health. In The Report of the British Nutrition Foundation Task Force; Goldberg, G., Ed.; Blackwell Science: Oxford, UK, 2003.

48. Afify, A.M.R.; El-Beltagi, H.S.; Abd El-Salam, S.M.; Omran, A.A. Effect of soaking, cooking, germination and fermentation processing on proximate analysis and mineral content of three white sorghum varieties (Sorghum bicolor L. Moench). Not. Bot. Horti Agrobot. Cluj-Napoca 2012, 40, 92-98.

49. Jambunathan, R. Improvement of the nutritional quality of sorghum and pearl millet. Food Nutr. Bull. 1980, 2, 11-16. [CrossRef]

50. Saxholt, E.; Christensen, A.T.; Møller, A.; Hartkopp, H.B.; Hess-Ygil, K.; Hels, O.H. Danish Food Composition Databank, revision 7. Department of Nutrition, National Food Institute, Technical University of Denmark: Kongens Lyngby, Denmark, 2008.

51. Pontieri, P.; Pepe, G.; Campiglia, P.; Merciai, F.; Basilicata, M.G.; Smolensky, D.; Calcagnile, M.; Troisi, J.; Romano, R.; Del Giudice, F.; et al. Comparison of content in phenolic compounds and antioxidant capacity in grains of white, red and black sorghum varieties grown in Mediterranean area. ACS Food Sci. Technol. 2021, 1, 1109-1119. [CrossRef] 